\title{
ANALISIS DAMPAK PENERAPAN AKUNTANSI BERBASIS AKRUAL TERHADAP PELAPORAN KEUANGAN BADAN PENGELOLA KEUANGAN DAN ASET DAERAH KABUPATEN MUSI BANYUASIN
}

\author{
JUMANIA SEPTARIANI, S.E., M.Si., Ak., CA. \\ STIE Rahmaniyah Sekayu \\ Email: jseptariani@gmail.com
}

\begin{abstract}
ABSTRAK
Penelitian ini membahas tentang dampak penerapan akuntansi berbasis akrual terhadap pelaporan keuangan Badan Pengelola Keuangan dan Aset Daerah Kabupaten Musi Banyuasin. Penelitian ini dilakukan pada Badan Pengelola Keuangan dan Aset Daerah (BPKAD) Kabupaten Musi Banyuasin. Penelitian ini termasuk jenis penelitian kualitatif. Data yang digunakan adalah dokumentasi dan wawancara. Analisis data yang digunakan adalah analisis deskriptif kualitatif. Hasil penelitian menunjukkan bahwa penerapan akuntansi berbasis akrual memiliki dampak dalam penyajian laporan keuangan BPKAD. Salah satunya perubahan komponen laporan keuangan yang sebelumnya tidak dijelaskan secara rinci menjadi lebih rinci sehingga lebih mudah dipahami dan diterima oleh pengguna, lebih akuntabel serta lebih relevan, meskipun masih ada kendala dalam mengkonversikan komponen tersebut sehingga terjadi keterlambatan waktu penyampaian laporan keuangan. BPKAD sebaiknya mengadakan pelatihan tentang pengelolaan SIMDA Keuangan bagi pegawai dan operator SIMDA setiap OPD serta menyeleksi pegawai yang memiliki latar belakang pendidikan yang sesuai dengan bidangnya agar lebih mempermudah penyajian laporan keuangan sesuai dengan Peraturan Pemerintah Nomor 71 Tahun 2010 dan Peraturan Menteri Dalam Negeri Nomor 63 Tahun 2016.

Kata kunci : SAP, Aset Daerah, Pengelola Keuangan Daerah, Basis Akrual
\end{abstract}

\section{LATAR BELAKANG}

Berlakunya Peraturan Pemerintah Nomor 71 Tahun 2010 tentang Standar Akuntansi Pemerintahan berbasis Akrual membawa perubahan besar dalam sistem pelaporan keuangan di Indonesia, yaitu perubahan dari basis kas menuju akrual menjadi basis akrual penuh dalam pengakuan transaksi keuangan pemerintah.

Perubahan basis tersebut selain telah diamanatkan oleh paket undangundang keuangan negara, juga diharapkan mampu memberikan gambaran yang utuh atas posisi keuangan, menyajikan informasi yang sebenarnya mengenai hak dan kewajiban, dan bermanfaat dalam mengevaluasi kinerja.

Menurut Peraturan Pemerintah Nomor 71 Tahun 2010 tentang Standar Akuntansi Pemerintahan, standar akuntansi pemerintahan berbasis akrual adalah standar akuntansi pemerintahan yang mengakui pendapatan, beban, aset, utang dan ekuitas dalam pelaporan finansial berbasis akrual serta mengakui pendapatan, belanja dan pembiayaan dalam pelaporan pelaksanaan anggaran basis yang ditetapkan dalam Anggaran Pendapatan Belanja Daerah (APBD). 
Tujuan umum pelaporan keuangan dengan basis akrual mempunyai peran akuntabilitas dan peran informatif, sehingga laporan keuangan dapat memberikan informasi kepada pengguna. Dengan laporan keuangan berbasis akrual, pengguna dapat melakukan penilaian atas kinerja keuangan, posisi keuangan, aliran arus kas suatu entitas, kepatuhan entitas terhadap peraturan perundang-undangan, regulasi, hukum dan perjanjian kontrak. Laporan keuangan berbasis akrual juga dapat membantu pengguna internal dalam pengambilan keputusan tentang penggunaan sumber daya dalam menjalankan suatu usaha. Untuk mewujudkannya diperlukan aparat pemerintah yang mampu menerapkan dalam praktiknya. Namun perubahan sebuah sistem akuntansi bukanlah hal yang mudah dilakukan.

Badan Pengelola Keuangan dan Aset Daerah (BPKAD) Kabupaten Musi Banyuasin merupakan Satuan Kerja Perangkat Daerah (SKPD) yang menyelenggarakan kewenangan Pemerintah Daerah Kabupaten Musi Banyuasin dalam rangka desentralisasi di bidang pengelolaan keuangan dan aset daerah. Laporan BPKAD pada tahun 2014 masih menggunakan basis kas menuju akrual, dan mulai tahun 2015 BPKAD mulai menerapkan basis akrual sampai tahun 2017 basis akrual telah di terapkan sepenuhnya.

Dalam penerapan akuntansi berbasis akrual berdampak pada perubahan komponen laporan keuangan yang sebelumnya tidak disajikan dalam laporan keuagan setelah berbasis akrual harus disajikan secara lebih rinci. Perubahan komponen keuangan tersebut menyebabkan staf BPKAD kesulitan dalam menkonversikan komponen laporan keuangan dari basis kas menuju akrual menjadi akrual sepenuhnya. Salah satunya dalam hal pendapatan dan biaya yang sebelumnya hanya disajikan dalam laporan realisasi anggaran tetapi setelah berbasis akrual akun pendapatan disajikan dalam laporan operasional dan akun biaya menjadi akun beban didalam laporan operasional.

Kesulitan mengkonversikan komponen laporan keuangan berbasis kas menuju akrual menjadi akrual harus juga mengakibatkan sering terjadinya kesalahan dan keterlambatan waktu penyampaian laporan keuangan kepada bagian Akuntansi BPKAD Kabupaten Musi Banyuasin. 


\section{KAJIAN PUSTAKA}

\section{Standar Akuntansi Pemerintahan (SAP)}

Berdasarkan Peraturan Pemerintah Nomor 71 Tahun 2010 Standar Akuntansi Pemerintahan (SAP) adalah prinsip-prinsip akuntansi yang diterapkan dalam menyusun dan menyajikan Laporan Keuangan Pemerintah yang terdiri atas Laporan Keuangan Pemerintah Pusat (LKPP) dan Laporan Keuangan Pemerintah Daerah (LKPD). Dengan demikian, SAP merupakan persyaratan yang mempunyai kekuatan hukum dalam upaya meningkatkan kualitas laporan keuangan pemerintah di Indonesia.

\section{Basis Standar Akuntansi Pemerintahan}

Darise (2008:38), Basis Akuntansi merupakan prinsip-prinsip akuntansi yang menentukan kapan pengaruh atas transaksi atau kejadian harus diakui untuk tujuan laporan keuangan. Basis akuntansi pada umumnya ada 2 (dua) yaitu basis kas dan basis akrual.

\section{Standar Akuntansi Pemerintahan Berbasis Kas}

Halim (2012:54), basis kas menetapkan bahwa pencatatan transaksi ekonomi hanya dilakukan apabila transaksi tersebut menimbulkan perubahan pada kas. Apabila suatu transaksi belum menimbulkan perubahan pada kas, maka transaksi tersebut tidak dicatat.

\section{Standar Akuntansi Pemerintahan Berbasis Akrual}

Halim (2012:54), basis akrual adalah dasar akuntansi yang mengakui transaksi dan peristiwa lainnya pada saat transaksi dan peristiwa itu terjadi dan bukan hanya pada saat kas atau setara kas diterima atau dibayar.

\section{Laporan Keuangan Pemerintah Daerah (LKPD)}

PSAP 01 (2010:6), laporan keuangan pemerintah daerah itu adalah gambaran mengenai kondisi dan kinerja keuangan entitas tersebut. Laporan keuangan pemerintah daerah menyajikan informasi yang berguna dalam pengambilan keputusan dan untuk menunjukkan akuntabilitas.

\section{Komponen Laporan Keuangan}

PSAP (2010:7), Komponen-komponen yang terdapat dalam satu set laporan keuangan terdiri dari laporan pelaksanaan anggaran (budgetary report) dan laporan finansial, sehingga seluruh komponen menjadi sebagai berikut : 
1. Laporan Realisasi Anggaran (LRA)

Laporan Realisasi Anggaran yang disingkat LRA adalah laporan yang menyajikan informasi realisasi pendapatan-LRA, belanja, transfer, surplus/defisit-LRA, pembiayaan, dan sisa lebih/kurang pembiayaan anggaran, yang masing-masing diperbandingkan dengan anggarannya dalam satu periode.

2. Laporan Perubahan Saldo Anggaran

Lebih Laporan Perubahan Saldo Anggaran Lebih yang disingkat LPSAL adalah laporan yang menyajikan informasi kenaikan dan penurunan SAL tahun pelaporan yang terdiri dari SAL awal, SiLPA/SiKPA, koreksi dan SAL akhir.

3. Neraca

Neraca adalah laporan yang menyajikan informasi posisi keuangan suatu entitas pelaporan menngenai aset, utang dan ekuitas dana pada tanggal tertentu.

4. Laporan Operasional

Laporan Operasional selanjutnya disingkat LO adalah laporan yang menyajikan infomasi mengenai seluruh kegiatan operasional keuangan entitas pelaporan yang tercermin dalam pendapatan-LO, beban dan surplus/defisit operasional dari suatu entitas pelaporan yang penyajiannya disandingkan dengan periode sebelumnya.

5. Laporan Arus Kas

Laporan Arus Kas selanjutnya disingkat LAK adalah laporan yang menyajikan informasi mengenai sumber, penggunaan, perubahan kas dan setara kas selama satu periode akuntansi, serta saldo kas dan setara kas pada tanggal pelaporan.

6. Laporan Perubahan Ekuitas

Laporan Perubahan Ekuitas selanjutnya disingkat LPE adalah laporan yang menyajikan informasi mengenai perubahan ekuitas yang terdiri dari ekuitas awal, surplus/defisit-LO, koreksi dan ekuitas akhir.

7. Catatan atas Laporan Keuangan 
CaLK adalah laporan yang menyajikan informasi tentang penjelasan atau daftar terinci atau analisis atas nilai suatu pos yang disajikan dalam LRA, LPSAL, LO, LPE, Neraca dan LAK dalam rangka pengungkapan yang memadai.

Untuk lebih jelas penyajian laporan keuangan pemerintah daerah yang berdasarkan SAP kas menuju akrual dan SAP berbasis akrual dapat dilihat dari tabel berikut :

Tabel 1

Penyajian laporan keuangan Pemerintah Daerah SAP Berbasis Kas Menuju Akrual dan SAP Berbasis Akrual

\begin{tabular}{|c|c|c|c|}
\hline No & Keterangan & $\begin{array}{c}\text { SAP Berbasis Kas Menuju } \\
\text { Akrual }\end{array}$ & SAP Berbasis Akrual \\
\hline 1 & $\begin{array}{l}\text { Komponen } \\
\text { keuangan }\end{array}$ & $\begin{array}{l}\text { Laporan keuangan pokok: } \\
\text { 1. Neraca } \\
\text { 2. Laporan } \\
\text { Anggaran } \\
\text { 3. Arus Kas } \\
\text { 4. Catatan atas Laporan } \\
\text { yang Bersifat Optional : } \\
\text { 1. Laporan Kinerja } \\
\text { Keuangan (LKK) } \\
\text { 2. Laporan Perubahan } \\
\text { Ekuitas (LPE) }\end{array}$ & \begin{tabular}{ll}
\multicolumn{3}{l}{ Laporan Anggaran : } \\
1. Laporan Realisasi \\
Anggaran (LRA) \\
2. Laporan Perubahan \\
Salso Anggaran \\
Lebih (SAL) \\
Laporan Finansial : \\
1. Neraca \\
2. Laporan Operasional \\
(LO) \\
3. Laporan Arus Kas \\
(LAK) \\
4. Laporan Perubahan \\
Ekuitas (LPE) \\
Catatan atas Laporan \\
Keuangan
\end{tabular} \\
\hline 2 & $\begin{array}{l}\text { Laporan Realisasi } \\
\text { Anggaran (LRA) }\end{array}$ & $\begin{array}{l}\text { Diperlukan dalam rangka } \\
\text { memenuhi kewajiban } \\
\text { pemerintah yang di atur dalam } \\
\text { perundangan }\end{array}$ & $\begin{array}{l}\text { Tetap diperlukan dalam } \\
\text { rangka } \\
\text { kewajiban memenuhi } \\
\text { yang di atur dalam } \\
\text { perundangan. }\end{array}$ \\
\hline
\end{tabular}




\begin{tabular}{|c|c|c|c|}
\hline No & Keterangan & $\begin{array}{c}\text { SAP Berbasis Kas Menuju } \\
\text { Akrual }\end{array}$ & SAP Berbasis Akrual \\
\hline 3 & $\begin{array}{l}\text { Laporan Perubahan } \\
\text { Saldo Anggaran Lebih } \\
\text { (LPSAL) }\end{array}$ & Tidak ada laporan & 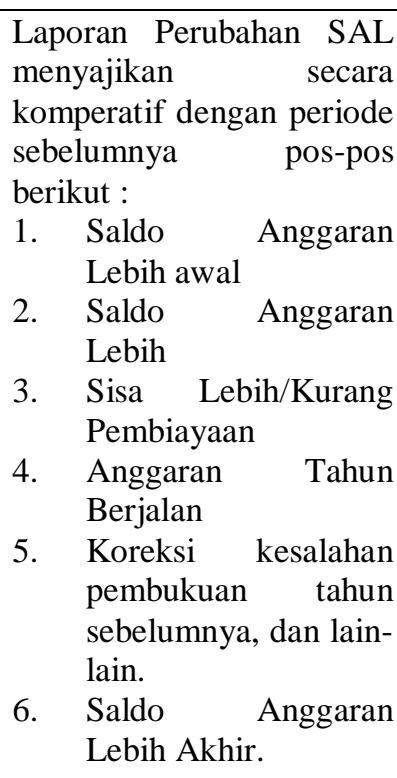 \\
\hline 4 & Neraca & $\begin{array}{l}\text { Akun Ekuitas disebut sebagai } \\
\text { Ekuitas Dana yang terbagi : } \\
\text { 1. } \quad \text { Ekuitas Dana Lancar } \\
\text { 2. } \quad \text { Ekuitas Dana Investasi } \\
\text { 3. } \quad \text { Ekuitas Dana Cadangan }\end{array}$ & $\begin{array}{l}\text { Tidak lagi disebut Ekuitas } \\
\text { Dana, hanya Ekuitas saja } \\
\text { yaitu kekayaan pemerintah } \\
\text { yang merupakan selisih } \\
\text { antara Aset dan Kewajiban } \\
\text { Pemerintah pada tanggal } \\
\text { Laporan. Saldo Ekuitas di } \\
\text { Neraca berasal dari Saldo } \\
\text { Ekuitas pada Laporan } \\
\text { Perubahan Ekuitas }\end{array}$ \\
\hline 5 & Laporan Arus Kas & 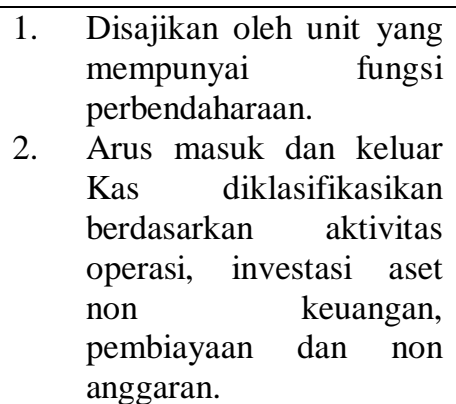 & $\begin{array}{l}\text { 1. Disajikan oleh unit yang } \\
\text { mempunyai fungsi } \\
\text { perbendaharaan. } \\
\text { 2. Arus masuk dan keluar } \\
\text { Kas diklasifikasikan } \\
\text { berdasarkan aktivitas } \\
\text { operasi, investasi aset non } \\
\text { keuangan, pembiayaan dan } \\
\text { non anggaran }\end{array}$ \\
\hline 6 & $\begin{array}{l}\text { Laporan } \\
\text { Keuangan } \\
\text { Opearsional }\end{array}$ & $\begin{array}{llr}\text { 1. } & \text { Bersifat Opsional. } \\
\text { 2. } & \begin{array}{l}\text { Disusun oleh Entitas } \\
\text { pelaporan }\end{array} \\
& \text { menyajikan } \quad \text { yang } \\
& \text { Berbasis Akrual } & \\
\end{array}$ & $\begin{array}{ll}\text { Merupakan } & \text { Laporan } \\
\text { Keuangan Pokok. } & \end{array}$ \\
\hline 7 & $\begin{array}{ll}\text { Laporan } & \text { Perubahan } \\
\text { Ekuitas } & \\
\end{array}$ & Bersifat opsional & $\begin{array}{ll}\text { Merupakan } & \text { Laporan } \\
\text { Keuangan Pokok } & \\
\end{array}$ \\
\hline 8 & $\begin{array}{l}\text { Catatan Atas Laporan } \\
\text { Keuangan }\end{array}$ & $\begin{array}{ll}\text { Disajikan secara } \\
\text { sistematis setiap pos } \\
\text { dalam LRA, Neraca, dan } \\
\text { LAK harus mempunyai } \\
\text { referensi silang dengan } \\
\text { informasi terkait dalam } \\
\text { Catatan atas Laporan }\end{array}$ & $\begin{array}{lrr}\text { Disajikan } & \text { secara } \\
\text { sistematis } & \text { setiap pos } \\
\text { dalam LRA, } & \text { Neraca, } \\
\text { dan LAK } & \text { harus } \\
\text { mempunyai } & \text { referensi } \\
\text { silang } & \text { dengan } \\
\text { informasi } & \text { terkait }\end{array}$ \\
\hline
\end{tabular}




\begin{tabular}{|c|c|c|c|}
\hline No & Keterangan & $\begin{array}{c}\text { SAP Berbasis Kas Menuju } \\
\text { Akrual }\end{array}$ & SAP Berbasis Akrual \\
\hline & & $\begin{array}{l}\text { Keuangan } \\
\text { CaLK meliputi } \\
\text { penjelasan atau daftar } \\
\text { terinciatau analisis atas } \\
\text { nilai suatu pos yan di } \\
\text { sajikan dalamLRA, } \\
\text { Neraca, dan LAK. }\end{array}$ & $\begin{array}{l}\text { dalam Catatan atas } \\
\text { Laporan Keuangan. } \\
\text { 2. } \\
\text { CaLK r meliputi } \\
\text { penjelasan atau daftar } \\
\text { terinciatau analisis } \\
\text { atas nilai suatu pos } \\
\text { yan di r sajikan } \\
\text { dalamLRA, Neraca, } \\
\text { dan LAK. }\end{array}$ \\
\hline
\end{tabular}

Sumber : Ratmono (2015:109)

\section{Indikator Penerapan Akuntansi Basis Akrual}

Menurut Peraturan Pemerintah Nomor 71 Tahun 2010 dalam penerapan laporan keuangan berbasis akrual terdapat 5 (lima) karakteristrik kualitatif laporan keuangan sebagai indikator yang diperlukan sebagai prasyarat tercapainya kualitas laporan keuangan yang dikehendaki yaitu :

1. Tepat waktu

Laporan keuangan harus disajikan tepat waktu agar dapat digunakan sebagai dasar pengambilan keputusan ekonomi, sosial, dan politik, serta untuk menghindari tertundanya pengambilan keputusan tersebut. Semakin banyak waktu yang dibutuhkan sehingga semakin membuat informasi tidak relevan.

2. Relevan

Laporan keuangan dapat dikatakan relevan apabila informasi yang termuat di dalamnya dapat mempengaruhi keputusan pengguna dengan membantu mereka mengevaluasi peristiwa masa lalu atau masa kini, dan memprediksi masa depan, serta menegaskan atau mengoreksi hasil evaluasi di masa lalu.

3. Andal

Informasi dalam laporan keuangan bebas dari pengertian yang menyesatkan dan kesalahan material, menyajikam setiap fakta secara jujur, serta dapat diverifikasi.

4. Dapat dibandingkan

Informasi yang termuat dalam laporan keuangan akan lebih berguna jika dapat dibandingkan dengan laporan keuangan periode sebelumnya atau laporan keuangan entitas pelaporan lain pada umumnya, baik secara internal maupun eksternal. 
5. Dapat dipahami

Informasi dalam laporan keuangan dapat dipahami oelh pengguna dan dinyatakan dalam bentuk istilah yang disesuaikan dengan batas pemahaman para pengguna. Untuk itu pengguna diasumsikan memiliki pengetahuan yang memadai atas kegiatan dan lingkungan operasi entitas pelaporan, serta adanya kemauan pengguna untuk mempelajari informasi yang dimaksud.

\section{Asumsi Dasar Pelaporan Keuangan}

Menurut Peraturan Pemerintah Nomor 71 Tahun 2010 (Lampiran I:9), Asumsi dasar dalam pelaporan keuangan di lingkungan pemerintah adalah anggapan yang diterima sebagai suatu kebenaran tanpa perlu dibuktikan agar standar akuntansi dapat diterapkan, yang terdiri dari 3 (tiga) asumsi yaitu :

1. Asumsi kemandirian entitas

Kemandirian entitas berarti bahwa setiap unit organisasi dianggap sebagai unit yang mandiri dan mempunyai kewajiban untuk menyajikan laporan keuangan sehingga tidak terjadi kekacauan antar unit instansi pemerintah dalam pelaporan keuangan.

2. Asumsi kesinambungan entitas

Laporan keuangan disusun dengan asumsi bahwa entitas pelaporan akan berlanjut keberadaannya. Dengan demikian, pemerintah diasumsikan tidak bermaksud melakukan likuidasi atas entitas pelaporan dalam jangka pendek.

3. Asumsi keterukuran dalam satuan uang (monetary measurement)

Laporan keuangan entitas pelaporan harus menyajikan setiap kegiatan yang di asumsikan dapat dinilai dengan satuan uang.

\section{METODE PENELITIAN}

\section{Tempat Penelitian}

Lokasi penelitian ini dilakukan pada Badan Pengelola Keuangan dan Aset Daerah Kabupaten Musi Banyuasin yang beralamat di Jalan Kolonel Wahid Udin Lk. VII, Kelurahan Serasan Jaya, Kecamatan Sekayu.

\section{Jenis dan Sumber Data}

Menurut Sugiyono (2012:137), dilihat dari jenis data yang digunakan dalam suatu penelitian adalah : 
a. Data Primer adalah data yang diperoleh langsung dari sumber asli (tidak melalui media perantara), data primer dapat berupa opini subjek (orang) secara individual atau kelompok, hasil obsevasi terhadap suatu benda atau fisik, kejadian atau kegiatan, dan hasil pengujian.

b. Data sekunder adalah data yang diperoleh atau dikumpulkan peneliti dari berbagai sumber yang telah ada, biasanya seudah dalam publikasi-publikasi.

Adapun jenis data yang digunakan Penulis pada penelitian ini adalah data sekunder berupa data yang diperoleh melalui wawanacara maupun dokumentasi, berupa Laporan Keuangan BPKAD Kabupaten Musi Banyuasin dari Tahun 2014 sampai dengan Tahun 2017.

\section{Teknik Pengumpulan Data}

Menurut Sugiyono (2012:132), data penelitian ini dikumpulkan dengan menggunakan metode sebagai berikut :

a. Studi Pustaka

Menelaah teori-teori yang bersumber dan buku-buku teks, teori-teori dan literatur, jurnal dan sebagainya untuk mendapatkan landasan teoritis yang berhubungan dengan penelitian.

b. Observasi

Penelitian melakukan pengamatan langsung ke objek penelitian dalam mengumpulkan data-data sebagai penunjang penelitian.

c. Wawancara

Yaitu melakukan wawancara atau tanya jawab dengan pihak-pihak terkait yang berhubungan dengan judul penelitian.

d. Dokumentasi

Yaitu mengumpulkan data dengan cara mengambil data-data dari catatan, dokumentasi, administrasi yang sesuai dengan masalah yang diteliti.

Adapun teknik pengumpulan data yang digunakan Penulis dalam penelitian ini yaitu dokumentasi, wawancara dan studi pustaka.

\section{Teknik Analisis Data}

Menurut Sugiyono (2012:131), teknik analisis data adalah proses mencari dan dan menyusun secara sistematis data yang diperoleh dari hasil wawancara, observasi lapangan, dan dokumentasi, dengan cara mengorganisasikan data ke 
dalam kategori, menjabarkan ke dalam pola, memilih mana yang penting dan yang akan dipelajari, dan membuat kesimpulan sehingga mudah dipahami oleh diri sendiri maupun orang lain. Dalam penelitian ini, Penulis menggunakan metode kualitatif. Metode kualitatif adalah penelitian yang menggunakan pendekatan naturalistik untuk mencari dan menemukan pemahaman tentang fenomena dalam latar belakang.

\section{ANALISIS DAN HASIL PEMBAHASAN}

\section{Analisis Penerapan Akuntansi Berbasis Akrual dalam Pelaporan Keuangan}

\section{Badan Pengelola Keuangan dan Aset Daerah Kabupaten Musi Banyuasin}

Laporan keuangan Badan Pengelola Keuangan dan Aset Daerah (BPKAD) Kabupaten Musi Banyuasin merupakan hasil dari pertanggungjawaban keuangan atas transaksi-transaksi yang dilakukan oleh BPKAD Kabupaten Musi Banyuasin dalam satu tahun anggaran yang disajikan secara lengkap sebagai salah satu bentuk transparansi dan akutabilitas, sebagaimana diamanatkan dalam tata kelola pemerintahan yang baik (good govermance).

BPKAD sebelumnya telah menerapkan akuntansi berbasis akrual walaupun belum dilakukan sepenuhnya. BPKAD telah menerapkan basis kas menuju akrual karena kebijakan akuntansi terkait dengan akumulasi aset tetap belum diterapkan.

Tabel 2

Rekapitulasi Komponen Laporan Keuangan BPKAD

\begin{tabular}{|c|c|c|c|}
\hline $\begin{array}{c}\text { Komponen Laporan } \\
\text { Keuangan }\end{array}$ & Basis Kas & $\begin{array}{c}\text { Basis Kas Menuju } \\
\text { Akrual }\end{array}$ & Basis Akrual \\
\hline $\begin{array}{l}\text { Laporan Realisasi } \\
\text { Anggaran (LRA) }\end{array}$ & $\begin{array}{ll}\text { Mencatat transaksi kas } \\
\text { dan non kas } \\
\text { Menyajikan pos-pos : } \\
\text { 1. } & \text { Pendapatan } \\
\text { 2. } & \text { Belanja } \\
\text { 3. } & \text { Transfer } \\
\text { 4. } & \text { Surplus/Defisit } \\
\text { 5. } & \text { Pembiayaan } \\
\text { 6. } & \text { SiLPA/SiKPA }\end{array}$ & $\begin{array}{l}\text { Mencatat transaksi kas } \\
\text { dan non kas } \\
\text { Menyajikan pos-pos : } \\
\text { 1. Pendapatan } \\
\text { 2. Belanja } \\
\text { 3. Transfer } \\
\text { 4. Surplus/Defisit } \\
\text { 5. Pembiayaan } \\
\text { 6. SiLPA/SiKPA }\end{array}$ & $\begin{array}{l}\text { Mencatat transaksi kas } \\
\text { saja } \\
\text { Menyajikan pos-pos : } \\
\text { 1. Pendapatan-LRA } \\
\text { 2. Belanja } \\
\text { 3. Transfer } \\
\text { 4. Surplus/Defisit-LRA } \\
\text { 5. Pembiayaan } \\
\text { 6. SiLPA/SiKPA }\end{array}$ \\
\hline Neraca & $\begin{array}{l}\text { Menyajikan pos-pos: } \\
\text { 1. Aset } \\
\text { Aset Lancar: } \\
\text { a) Kas dan setara kas } \\
\text { b) Investasi jangka } \\
\text { pendek } \\
\text { c) Piutang pajak dan } \\
\text { bukan pajak } \\
\text { d) Persediaan } \\
\text { Aset non lancar: }\end{array}$ & $\begin{array}{l}\text { Menyajikan pos-pos : } \\
\text { 1. Aset } \\
\text { Aset Lancar: } \\
\text { e) Kas dan setara kas } \\
\text { f) Investasi jangka } \\
\text { pendek } \\
\text { g) Piutang pajak dan } \\
\text { bukan pajak } \\
\text { h) Persediaan } \\
\text { Aset non lancar : }\end{array}$ & $\begin{array}{l}\text { Menyajikan pos-pos: } \\
\text { 1. Aset } \\
\text { Aset lancar: } \\
\text { a) Kas dan setara kas } \\
\text { b) Investasi jangka } \\
\text { pendek } \\
\text { c) Piutang (penyisihan } \\
\text { piutang, Belanja dibayar } \\
\text { dimuka) } \\
\text { d) Persediaan }\end{array}$ \\
\hline
\end{tabular}


Jurnal Ilmiah Akuntansi Rahmaniyah (JIAR)

Vol. 2 No.1, Desember 2018, 32 - 51

Septariani

\begin{tabular}{|c|c|c|c|}
\hline $\begin{array}{c}\text { Komponen Laporan } \\
\text { Keuangan }\end{array}$ & Basis Kas & $\begin{array}{c}\text { Basis Kas Menuju } \\
\text { Akrual }\end{array}$ & Basis Akrual \\
\hline & $\begin{array}{l}\text { a) Investasi jangka } \\
\text { panjang } \\
\text { b) Aset tetap } \\
\text { 2. Kewajiban : } \\
\text { a) Kewajiban jangka } \\
\text { pendek } \\
\text { b) Kewajijban jangka } \\
\text { panjang } \\
\text { 3. Ekuitas Dana: } \\
\text { a) Ekuitas Dana Lancar } \\
\text { b) Ekuitas Dana Investasi } \\
\text { c) Ekuitas Dana } \\
\text { Cadangan }\end{array}$ & 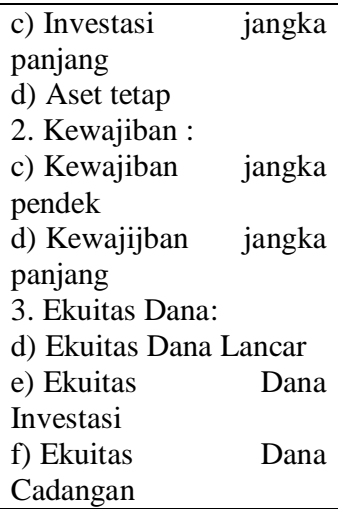 & $\begin{array}{lr}\text { e) Investasi } & \text { jangka } \\
\text { panjang. } & \\
\text { Aset tetap } & \\
\text { 2. Kewajiban } & \\
\text { a) Kewajiban } & \text { jangka } \\
\text { pendek (utang } & \text { belanja, } \\
\text { pendapatan } & \text { diterima } \\
\text { dimuka) } & \\
\text { b) Kewajiban } & \text { jangka } \\
\text { panjang. } & \\
\text { 3. Ekutas } & \end{array}$ \\
\hline $\begin{array}{l}\text { Laporan Perubahan } \\
\text { Saldo Anggaran Lebih } \\
\text { (LPSAL) }\end{array}$ & $\begin{array}{c}\text { Tidak ada laporan } \\
\text { LPSAL }\end{array}$ & $\begin{array}{c}\text { Tidak ada laporan } \\
\text { LPSAL }\end{array}$ & $\begin{array}{l}\text { Menyajikan pos-pos: } \\
\text { LPSAL menyajikan } \\
\text { secara komparatif dengan } \\
\text { periode sebelumnya pos- } \\
\text { pos berikut: } \\
\text { 1. Saldo Anggaran } \\
\text { Lebih tahun lalu } \\
\text { 2. Penggunaan Saldo } \\
\text { Anggaran Lebih } \\
\text { 3. SiLPA/SiKPA } \\
\text { 4. Koreksi kesalahan } \\
\text { pembukuan tahun } \\
\text { sebelumnya } \\
\text { 5. Saldo Anggaran } \\
\text { Lebih Tahun } \\
\text { berjalan }\end{array}$ \\
\hline $\begin{array}{c}\text { Laporan Operasional } \\
\text { (LO) }\end{array}$ & $\begin{array}{c}\text { Tidak ada laporan } \\
\text { operasional }\end{array}$ & $\begin{array}{c}\text { Tidak ada laporan } \\
\text { operasional }\end{array}$ & $\begin{array}{ll}\text { Menyajikan pos-pos } \\
\text { sebagai berikut: } \\
\text { 1. } & \text { Pendapatan-LO } \\
\text { 2. } & \text { Beban dari } \\
& \text { kegiatan } \\
& \text { operasional } \\
\text { 3. } & \text { Surplus/Defisit dari } \\
& \text { kegiatan non } \\
& \text { operasional } \\
\text { 4. } & \text { Pos luar biasa } \\
\text { 5. } & \text { Surplus/Defisit-LO }\end{array}$ \\
\hline $\begin{array}{l}\text { Laporan Arus Kas } \\
\text { (LAK) }\end{array}$ & $\begin{array}{l}\text { Disajikan oleh unit yang } \\
\text { memiliki fungsi } \\
\text { perbendaharaan. } \\
\text { Arus Masuk dan Keluar } \\
\text { Kas diklasifikasikan } \\
\text { berdasarkan: } \\
\text { 1. Aktivitas Operasi } \\
\text { 2. Aktivitas Investasi } \\
\text { Aset Non } \\
\text { Keuangan } \\
\text { 3. Aktivitas } \\
\text { Pembiayaan } \\
\text { 4. Aktivitas Non } \\
\text { Anggaran }\end{array}$ & $\begin{array}{l}\text { Disajikan oleh unit yang } \\
\text { memiliki fungsi } \\
\text { perbendaharaan. } \\
\text { Arus Masuk dan Keluar } \\
\text { Kas diklasifikasikan } \\
\text { berdasarkan: } \\
\text { 5. Aktivitas Operasi } \\
\text { 6. Aktivitas Investasi } \\
\text { Aset Non } \\
\text { Keuangan } \\
\text { 7. Aktivitas } \\
\text { Pembiayaan } \\
\text { 8. Aktivitas Non } \\
\text { Anggaran } \\
\end{array}$ & $\begin{array}{l}\text { Disajikan oleh unit yang } \\
\text { mempunyai fungsi } \\
\text { perbendaharaan umum. } \\
\text { Arus Masuk dan Keluar } \\
\text { Kas diklasifikasikan } \\
\text { berdasarkan: } \\
\text { 1. Aktivitas Operasi } \\
\text { 2. Aktivitas Investasi } \\
\text { 3. Aktivitas } \\
\quad \text { Pendanaan } \\
\text { Aktivitas Transitoris }\end{array}$ \\
\hline $\begin{array}{l}\text { Laporan Perubahan } \\
\text { Ekuitas (LPE) }\end{array}$ & $\begin{array}{l}\text { Tidak ada laporan } \\
\text { perubahan ekuitas }\end{array}$ & $\begin{array}{l}\text { Tidak ada laporan } \\
\text { perubahan ekuitas }\end{array}$ & $\begin{array}{ll}\text { Menyajikan pos-pos } \\
\text { sebagai berikut: } \\
\text { 1. Ekuitas Awal } \\
\text { 2. Surplus/Defisit-LO } \\
\text { 3. Koreksi-koreksi } \\
\begin{array}{l}\text { yang langsung }\end{array}\end{array}$ \\
\hline
\end{tabular}




\begin{tabular}{|c|c|c|c|}
\hline $\begin{array}{c}\text { Komponen Laporan } \\
\text { Keuangan }\end{array}$ & Basis Kas & $\begin{array}{c}\text { Basis Kas Menuju } \\
\text { Akrual }\end{array}$ & Basis Akrual \\
\hline & & & $\begin{array}{l}\text { menambah/mengur } \\
\text { angi ekuitas: } \\
\text { a. Koreksi nilai } \\
\text { persediaan } \\
\text { b. Selisih } \\
\\
\quad \text { revaluasi aset } \\
\quad \text { tetap } \\
\text { 4. Ekuitas Akhir }\end{array}$ \\
\hline $\begin{array}{l}\text { Catatan Atas Laporan } \\
\text { Keuangan (CaLK) }\end{array}$ & $\begin{array}{l}\text { CaLK meliputi } \\
\text { penjelasan atau daftar } \\
\text { terinci atau analisis atas } \\
\text { nilai suatu pos yang } \\
\text { disajikan dalam LRA, } \\
\text { Neraca dan LAK. } \\
\text { Disajikan secara } \\
\text { sistematis setiap pos } \\
\text { dalam LRA, Neraca, } \\
\text { LAK harus mempunyai } \\
\text { referensi silang dengan } \\
\text { informasi terkait dalam } \\
\text { Catatan atas Laporan } \\
\text { Keuangan. } \\
\text { Kebijakan akuntansi } \\
\text { yang perlu } \\
\text { dipertimbangkan untuk } \\
\text { disajikan adalah: } \\
\text { 1. Pengakuan } \\
\text { 2. Pendapatan } \\
\text { 2. Pengakuan belanja }\end{array}$ & $\begin{array}{l}\text { CaLK meliputi } \\
\text { penjelasan atau daftar } \\
\text { terinci atau analisis atas } \\
\text { nilai suatu pos yang } \\
\text { disajikan dalam LRA, } \\
\text { Neraca dan LAK. } \\
\text { Disajikan secara } \\
\text { sistematis setiap pos } \\
\text { dalam LRA, Neraca, } \\
\text { LAK harus mempunyai } \\
\text { referensi silang dengan } \\
\text { informasi terkait dalam } \\
\text { Catatan atas Laporan } \\
\text { Keuangan. } \\
\text { Kebijakan akuntansi } \\
\text { yang perlu } \\
\text { dipertimbangkan untuk } \\
\text { disajikan adalah: } \\
\text { 1. Pengakuan } \\
\text { 2. Pendapatan } \\
\text { Pengakuan belanja }\end{array}$ & $\begin{array}{l}\text { CaLK meliputi penjelasan } \\
\text { atau daftar terinci atau } \\
\text { analisis atas nilai suatu } \\
\text { pos yang disajikan dalam } \\
\text { LRA, LPSAL, Neraca, } \\
\text { LO, LAK dan LPE. } \\
\text { Disajikan secara } \\
\text { sistematis setiap pos } \\
\text { dalam LRA, LPSAL, } \\
\text { Neraca, LO, LAK dan } \\
\text { LPE harus mempunyai } \\
\text { referensi silang dengan } \\
\text { informasi terkait dalam } \\
\text { Catatan atas Laporan } \\
\text { Keuangan. } \\
\text { Kebijakan akuntansi } \\
\text { yang perlu } \\
\text { dipertimbangkan untuk } \\
\text { disajikan adalah: } \\
\text { 1. Pengakuan } \\
\text { 2. Pendapatan-LRA } \\
\text { 3. pengakuan } \\
\text { 4. Pengakuanan belanja } \\
\text { 4. Pengakuan beban }\end{array}$ \\
\hline
\end{tabular}

Sumber : BPKAD, Tahun 2018, data diolah

\section{Penyajian Laporan Keuangan BPKAD Sebelum dan Setelah Berbasis Akrual}

Laporan keuangan BPKAD mengalami beberapa perubahan komponen dalam penyajian laporan keuangan dari sebelum dan menerapkan akuntansi berbasis akrual dan setelah menerapkan basis akrual. Perubahan komponen tersebut yaitu : 


\section{Jurnal Ilmiah Akuntansi Rahmaniyah (JIAR)}

Vol. 2 No.1, Desember 2018, 32 - 51

Septariani

Tabel 3

Rekapitulasi Pos-pos dalam Laporan Keuangan BPKAD

\begin{tabular}{|c|c|c|c|}
\hline Komponen Laporan Keuangan & Basis Kas & Basis Kas Menuju Akrual & Basis Akrual \\
\hline Laporan Realisasi Anggaran & $\begin{array}{l}\text { Pendapatan } \\
\text { Pendapatan Asli Daerah } \\
\text { Pendapatan Pajak Daerah } \\
\text { Pendapatan Hasil Pengelola Kekayaan Daerah } \\
\text { yang Dipisahkan } \\
\text { Lain-lain PAD yang Sah } \\
\text { Belanja } \\
\text { Belanja Tidak Langsung } \\
\text { Belanja Pegawai } \\
\text { Belanja Langsung } \\
\text { Belanja Pegawai } \\
\text { Belanja Barang/Jasa } \\
\text { Belanja Modal } \\
\text { SURPLUS/DEFISIT } \\
\text { SISA LEBIH/KURANG PEMBIAYAAN } \\
\text { TAHUN BERKENAN }\end{array}$ & $\begin{array}{l}\text { Pendapatan } \\
\text { Pendapatan Asli Daerah } \\
\text { Pendapatan Pajak Daerah } \\
\text { Pendapatan Hasil Pengelola Kekayaan Daerah } \\
\text { yang Dipisahkan } \\
\text { Lain-lain PAD yang Sah } \\
\text { Belanja } \\
\text { Belanja Tidak Langsung } \\
\text { Belanja Pegawai } \\
\text { Belanja Langsung } \\
\text { Belanja Pegawai } \\
\text { Belanja Barang/Jasa } \\
\text { Belanja Modal } \\
\text { SURPLUS/DEFISIT } \\
\text { SISA LEBIH/KURANG PEMBIAYAAN TAHUN } \\
\text { BERKENAN }\end{array}$ & $\begin{array}{l}\text { Pendapatan-LRA } \\
\text { Pendapatan Asli Daerah-LRA } \\
\text { Pendapatan Pajak Daerah-LRA } \\
\text { Pendapatan Hasil Pengelola Kekayaan Daerah } \\
\text { yang Dipisahkan-LRA } \\
\text { Lain-Lain PAD yang Sah } \\
\text { Belanja } \\
\text { Belanja Operasi } \\
\text { Belanja Pegawai } \\
\text { Belanja Barang dan Jasa } \\
\text { Belanja Modal } \\
\text { Belanja Modal Peralatan dan Mesin } \\
\text { Belanja Modal Gedung dan Bangunan } \\
\text { Belanja Modal Jalan, Irigasi, dan Jaringan } \\
\text { Belanja Modal Aset Tetap Lainnya } \\
\text { SURPLUS/DEFISIT } \\
\text { SISA LEBIH/KURANG PEMBIAYAAN } \\
\text { TAHUN BERKENAAN }\end{array}$ \\
\hline Neraca & $\begin{array}{l}\text { Aset } \\
\text { Aset Lancar } \\
\text { Aset Tetap } \\
\text { Dana Cadangan } \\
\text { Aset Lainnya } \\
\text { Kewajiban } \\
\text { Kewajiban Jangka Pendek } \\
\text { Kewajiban Jangka Panjang } \\
\text { Ekuitas Dana } \\
\text { Ekuitas Dana Lancar } \\
\text { Ekuitas Dana Investasi } \\
\text { Ekuitas Dana Cadangan }\end{array}$ & $\begin{array}{l}\text { Aset } \\
\text { Aset Lancar } \\
\text { Aset Tetap } \\
\text { Dana Cadangan } \\
\text { Aset Lainnya } \\
\text { Kewajiban } \\
\text { Kewajiban Jangka Pendek } \\
\text { Kewajiban Jangka Panjang } \\
\text { Ekuitas Dana } \\
\text { Ekuitas Dana Lancar } \\
\text { Ekuitas Dana Investasi } \\
\text { Ekuitas Dana Cadangan }\end{array}$ & $\begin{array}{l}\text { Aset } \\
\text { Aset Lancar } \\
\text { Investasi Jangka Panjang } \\
\text { Aset Tetap } \\
\text { Dana Cadangan } \\
\text { Aset Lainnya } \\
\text { Kewajiban } \\
\text { Kewajiban Jangka Pendek } \\
\text { Kewajiban Jangka Panjang } \\
\text { Ekuitas }\end{array}$ \\
\hline
\end{tabular}




\section{Jurnal Ilmiah Akuntansi Rahmaniyah (JIAR)}

Vol. 2 No.1, Desember 2018, 32 - 51

Septariani

\begin{tabular}{|c|c|c|c|}
\hline Komponen Laporan Keuangan & Basis Kas & Basis Kas Menuju Akrual & Basis Akrual \\
\hline $\begin{array}{l}\text { Laporan Perubahan Saldo } \\
\text { Anggaran Lebih }\end{array}$ & Tidak Ada Laporan & Tidak Ada Lapoaran & $\begin{array}{l}\text { Saldo Anggaran Lebih Awal } \\
\text { Penggunaan Saldo Anggaran Lebih } \\
\text { Subtotal } \\
\text { Sisa Anggaran Tahun Berjalan } \\
\text { Subtotal } \\
\text { Koreksi kesalahan Pembukuan Tahun } \\
\text { Sebelumnya } \\
\text { Lain-lain } \\
\text { Saldo Anggaran Lebih Akhir }\end{array}$ \\
\hline Laporan Operasional & Tidak Ada Laporan & Tidak Ada Laporan & $\begin{array}{l}\text { Kegiatan Operasional } \\
\text { Pendapatan } \\
\text { Pendapatan Asli Daerah } \\
\text { Pendapatan Transfer } \\
\text { Lain-lain Pendapatan Yang Sah } \\
\text { Beban } \\
\text { Surplus/Defisit dari Operasi } \\
\text { Surplus/Defisit dari Kegiatan Non Operasional } \\
\text { Surplus/Defisit Sebelum Pos Luar Biasa } \\
\text { Pos Luar Biasa } \\
\text { Surplus/Defisit LO }\end{array}$ \\
\hline Laporan Perubahan Ekuitas & Tidak Ada Laporan & Tidak Ada Laporan & $\begin{array}{l}\text { Ekuitas Awal } \\
\text { Surplus/defisit-LO } \\
\text { Dampak Kumulatif Perubahan } \\
\text { Kebijakan/Kesalahan Mendasar : } \\
\text { Koreksi Nilai Persediaan } \\
\text { Selisih Revaluasi Aset Tetap }\end{array}$ \\
\hline Laporan Arus Kas & & $\begin{array}{l}\text { Arus Kas dari Aktivitas Operasi } \\
\text { Arus Kas Masuk } \\
\text { Arus Kas Keluar }\end{array}$ & $\begin{array}{l}\text { Arus Kas dari Aktivitas Operasi } \\
\text { Arus Kas Masuk } \\
\text { Arus Kas Keluar }\end{array}$ \\
\hline
\end{tabular}


Jurnal Ilmiah Akuntansi Rahmaniyah (JIAR)

Vol. 2 No.1, Desember 2018, 32 - 51

Septariani

\begin{tabular}{|c|c|c|c|}
\hline Komponen Laporan Keuangan & Basis Kas & Basis Kas Menuju Akrual & Basis Akrual \\
\hline & & $\begin{array}{l}\text { Arus Kas Bersih dari Aktivitas Operasi } \\
\text { Arus Kas dari Aktivitas Investas Aset Nonkeuangan } \\
\text { Arus Kas Masuk } \\
\text { Arus Kas Keluar } \\
\text { Arus Kas Bersih dari Aktivitas Investasi Aset } \\
\text { Nonkeuangan } \\
\text { Arus Kas dari Aktivitas Pembiayaan } \\
\text { Arus Kas Masuk } \\
\text { Arus Kas Keluar } \\
\text { Arus Kas Bersih dari Aktivitas Pembiayaan } \\
\text { Arus Kas dari Aktivitas Non Anggaran } \\
\text { Arus Kas Masuk } \\
\text { Arus Kas Keluar } \\
\text { Arus Kas Bersih dari Aktivitas Non Anggaran } \\
\text { Kenaikan/Penurunan Kas } \\
\text { Saldo Awal Kas di BUD } \\
\text { Saldo Akhir di BUD } \\
\text { Saldo Akhir Kas di Bendahara Pengeluaran } \\
\text { Saldo Akhir Kas di Bendahara Penerimaan } \\
\text { Saldo Akhir Kas }\end{array}$ & $\begin{array}{l}\text { Arus Kas Bersih dari Aktivitas Operasi } \\
\text { Arus Kas dari Aktivitas Investasi } \\
\text { Arus Kas Masuk } \\
\text { Arus Kas Keluar } \\
\text { Arus Kas Bersih dari Aktivitas Investasi } \\
\text { Arus Kas dari Aktivitas Pendanaan } \\
\text { Arus Kas Masuk } \\
\text { Arus Kas Keluar } \\
\text { Arus Kas Bersih dari Aktivitas Pendanaan } \\
\text { Arus Kas dari Aktivitas Transitoris } \\
\text { Arus Kas Masuk } \\
\text { Arus Kas Keluar } \\
\text { Arus Kas Bersih dari Aktivitas Transitoris } \\
\text { Kenaikan/Penurunan Kas } \\
\text { Saldo Awal Kas di BUD \& Kas di Bendahara } \\
\text { Pengeluaran } \\
\text { Saldo Akhir Kas di BUD \& Kas di Bendahara } \\
\text { Pengeluaran } \\
\text { Saldo Akhir Kas di Bendahara Penerimaan } \\
\text { Saldo Akhir Kas }\end{array}$ \\
\hline
\end{tabular}

Sumber: BPKAD, Tahun 2018, Data diolah. 


\section{Dampak Penerapan Akuntani Setelah Berbasis Akrual}

Penerapan Akuntansi Berbasis Akrual memiliki banyak dampak dalam pelapooran keuangan BPKAD. Basis akrual menyajikan informasi terkait tentang kas dan informasi tambahan secara menyeluruh. Sedangkan dalam pengelolaan aset non keuangan basis akrual menyediakan informasi mengenai aset. Basis akrual juga menyediakan informasi yang akuntabel dan lebih sederhana untuk menilai instansi dan kreditur.

Penyajian laporan keuangan BPKAD Kabupaten Musi Banyuasin setelah menerapkan Basis Akrual yaitu, komponen laporan keuangannya terdirir dari :

1. Laporan Realisasi Anggaran (LRA)

Perubahan komponen LRA setelah menerapkan basis akrual yaitu pada pos akun pendapatan yang sebelumnya pos pendapatan menyajikan seluruh pendapatan yang dihasilkan dari transaksi kas dan non keuangan menjadi Pendapatan-LRA yang menyajikan perbandingan Anggaran pendapatan yang ditargetkan dengan Realisasi pendapatan-LRA yang dihasilkan dari transaksi kas.

Akun pos Belanja yang dari sebelumnya akun belanja dibagi menjadi dalam 2 (dua) pos yaitu pos belanja langsung dan belanja tidak langsung, setelah menerapkan basis akrual penuh pos belanja lebih disederhanakan menjadi 1 (satu) pos yaitu pos belanja saja.

2. Neraca

Perubahan komponen Laporan Neraca BPKAD setelah menerapkan basis akrual sepernuhnya yaitu dari pos Ekuitas yang sebelumnya disebut Ekuitas Dana dan terbagi menjadi 3 (tiga) pos yaitu Ekuitas Dana Lancar, Ekuitas Dana Investasi, dan Ekuitas Dana Cadangan, menajadi pos akun Ekuitas saja. Dalam Akun Aset Lancar juga terdapat tambahan pos akun yaitu pos penyisihan piutang dan belanja dibayar dimuka. Sedangkan dalam pos akun Kewajiban Jangka Pendek terdapat tambahan pos akun utang belanja dan pendapatan diterima dimuka.

3. Laporan Perubahan Saldo Anggaran Lebih (LPSAL)

LPSAL dari yang sebelumnya tidak digunakan oleh BPKAD sebagai salah satu komponen laporan keuangan BPKAD setelah menerapkan basis akrual 
sepenuhnya LPSAL menjadi salah satu komponen laporan keuangan yang harus disajikan.

4. Laporan Operasional

Laporan Operasional (LO) dari yang sebelumnya tidak digunakan oleh BPKAD sebagai salah satu komponen laporan keuangan BPKAD setelah menerapkan basis akrual sepenuhnya LO menjadi salah satu komponen laporan keuangan yang harus disajikan. LO mencatat transaksi yang berkaitan dengan non kas, dalam LO menyajikan Pendapatan-LO dan Beban yang dihasilkan dari kegiatan operasional serta surplus/defisit dari kegiatan non operasional.

5. Laporan Perubahan Ekuitas (LPE)

Laporan Perubahan Ekuitas (LPE) sebelumnya tidak digunakan oleh BPKAD sebagai komponen laporan. Setelah menerapkan basis akrual penuh LPE digunakan sebagai salah satu komponen laporan yang harus di laporkan oleh BPKAD.

\section{Laporan Arus Kas}

Perubahan Laporan Arus Kas BPKAD setelah menerapkan basis akrual yaitu menyajikan informasi mengenai sumber, penggunaan, perubahan kas dan setara kas yang terjadi di BPKAD dalam satu periode pelaporan akuntansi dan saldo kas dan setara kas pada tanggal pelaporan. Arus kas masuk dan kas keluar diklasifikasikan berdasarkan Aktivitas Operasi, Aktivitas Investasi, Aktivitas Pendanaan, dan Aktivitas Transitoris.

\section{Catatan Atas Laporan Keuangan (CALK)}

CALK menyajikan secara sistematis setiap pos dalam Laporan Realisasi Anggran, Laporan Perubahan Saldo Anggaran Lebih, Neraca, Laporan Operasional, Laporan Arus Kas, dan Laporan Perubahan Ekuitas. CALK juga menyajikan kebijakan-kebijakan yang digunakan oleh BPKAD dan Pengungkapan-pengungkapan yang diharuskan untuk diungkapkan dalam CALK.

Selain dari perubahan komponen laporan keuangan dampak dari penerapan akuntansi berbasis akrual yaitu pencapaian opini Wajar Tanpa Pengecualian (WTP) karena informasi yang diberikan lebih handal, relevan dan dapat dibandingkan sehingga mudah dipahami oleh pengguna laporan keuangan 
dan mempermudah dalam pengambilan keputusan ekonomi serta dapat memprediksi anggaran pada periode berikutnya.

Hal tersebut menunjukan bahwa penerapan akuntansi berbasis akrual di BPKAD dapat dikatakan baik daripada sebelum menerapkan basis akrual. Namun masih ada kelemahan dalam penerapan akuntansi berbasis akrual ini yaitu, sulitnya mengkonversikan perubahan komponen laporan keuangan yang sebelumnya tidak disajikan dalam laporan keuangan oleh sebagian SKPD di Kabupaten Musi Banyuasin sehingga sering terjadinya keterlambatan waktu penyampaian laporan keuangan kepada bagian Akuntansi BPKAD. Hal ini disebabkan tidak semua pegawai yang mengelola SIMDA keuangan memiliki latar pendidikan yang sama dan paham dalam pengelolaan keuangan pemerintah daerah Kabupaten Musi Banyuasin.

\section{SIMPULAN DAN SARAN}

\section{Simpulan}

Berdasarkan hasil pembahasan dan analisis, maka dapat disimpulkan tentang Penerapan dan Dampak Penerapan Akuntansi Berbasis Akrual Terhadap Pelaporan Keuangan Badan Pengelola Keuangan dan Aset Daerah Kabupaten Musi Banyuasin sebagai berikut :

1. Dampak penerapan akuntansi berbasis akrual yaitu perubahan komponen laporan keuangan yang disajikan lebih rinci mengenai seluruh kegiatan operasional keuangan, perubahan saldo anggaran lebih, juga informasi mengenai aset dan penyesutuan aset tetap sehingga informasi yang diberikan lebih mudah dipahami dan dimengerti, lebih relevan, andal dan dapat dibandingkan sehingga mempermudah dalam pengambilan keputusan ekonomi serta dapat memprediksi anggaran pada periode berikutnya. Namun masih terdapat kelemahan dalam penerapan akuntansi berbasis akrual yaitu sulitnya mengkonversikan perubahan komponen laporan keuangan tersebut sehingga masih sering terjadi keterlambatan waktu penyampaian laporan keuangan. 


\section{Saran}

1. Sebaiknya dalam mengimplementasikan SAP berbasis akrual khususnya BPKAD Kabupaten Musi Banyuasin, perlu adanya upaya ekselerasi sinkronisasi SAP berbasis akrual dengan peraturan lokal di Pemerintahan Daerah.

2. Sulitnya mengkonversikan komponen laporan keuangan dengan demikian perlu adanya pengembangan dan pemahaman para pengelola keuangan. Sebaiknya BPKAD mengadakan pelatihan untuk pegawai yang menjadi operator SIMDA keuangan dan mengadakan sosialisasi berupa seminar berkaitan dengan SAP berbasis akrual tersebut.

\section{DAFTAR PUSTAKA}

Bastian, Indra. 2010. Akuntansi Sektor Publik. Edisi Ketiga. Jakarta : Erlangga

Halim, Abdul dan Kusufi, Muhammad Syam. 2012. Akuntansi Sektor Publik Akuntansi Keuangan Daerah. Edisi 4. Jakarta : Salemba Empat

Langelo, F., D. P. E. Saerang, dan S.W. Alexander. 2015. Analisis Penerapan Akuntansi Pemerintahan Berbasis Akrual Dalam Penyajian Laporan Keuangan Pada Pemerintah Kota Bitung. Jurnal EMBA 1 V 3 (1), 1-8. http://ejournal.unsrat.ac.id/index.php/emba/article/view/6556. diakses tanggal 10 juli 2018. pukul 14:00 wib.

Nordiawan, Deddi, Iswahyudi Sondi, dan Maulidah, Rahmawati. 2012. Akuntansi Pemerintahan, Jakarta : Salemba Empat.

Nordiawan, Deddi, dan Hertianti, Ayuningtyas. 2010. Akuntansi Sektor Publik, Edisi 2, Jakarta: Salemba Empat.

Nurlan, Darise. 2008. Akuntansi Keuangan Daerah. Jakarta: PT INDEKS.

Pemerintah Republik Indonesia, 2010. Peraturan Pemerintah Nomor 71 Tahun 2010 tentang Standar Akuntansi Pemerintah.

Peraturan Menteri Dalam Negeri Nomor 64 Tahun 2013. tentang Penerapan Standar Akuntansi Pemerintahan Berbasis Akrual Pada Pemerintah Daerah.

Sugiyono. 2012. Metode Penelitian Kuantitatif Kualitatif dan R\&D. Bandung: Alfabeta 
Jurnal Ilmiah Akuntansi Rahmaniyah (JIAR)

Vol. 2 No.1, Desember 2018, 32 - 51

Satrio, M. Dimas., Yuhertiana, Indrawati., Hamzah, Ardi. 2016. Implementasi Standar Akuntansi Pemerintah Berbasis Akrual di Kabupaten Jombang. Jurnal Akuntansi dan Keuangan Vol. 18, No 1, 59-70. 